\title{
Integrating Unmanned Aircraft Systems to Measure Linear and Areal Features into Undergraduate Forestry Education
}

\author{
Reid A. Viegut ${ }^{1}$, David L. Kulhavy ${ }^{1}$, Daniel R. Unger ${ }^{1}$, I-Kuai Hung ${ }^{1} \&$ Brian Humphreys ${ }^{1}$ \\ ${ }^{1}$ Arthur Temple College of Forestry and Agriculture, Stephen F. Austin State University, Nacogdoches, Texas, USA \\ Correspondence: David L. Kulhavy, Arthur Temple College of Forestry and Agriculture, Stephen F. Austin State \\ University, Nacogdoches, Texas, U.S.A.
}

Received: July 11, 2018

Accepted: July 30, 2018

Online Published: August 3, 2018

doi:10.5430/ijhe.v7n4p63

URL: https://doi.org/10.5430/ijhe.v7n4p63

\begin{abstract}
The use of Unmanned Aircraft Systems (UAS) in undergraduate forestry education continues to expand and develop. Accuracy of data collection is an important aspect of preparation for "society-ready" foresters to meet the complex sustainable environment managing for ecological, social and economic interests. Hands-on use of a DJI Phantom 4 Pro UAS by undergraduates to measure the length and area of 30 linear features and areal features on Earth's surface were estimated. These measurements were compared (measured within the ArcMap 10.5.2 interface) to hyperspectral Pictometry imagery measured on the web-based interface and the Google Earth Pro interface. Each remotely estimated measurement was verified with the actual ground measurements and the methods compared. An analysis of variance, conducted on the absolute length errors resulting in a p-value of 0.000057 , concluded that the three length estimating techniques were statistically different at a $95 \%$ confidence interval. A Tukey pair-wise test found that the remotely sensed DJI Phantom 4 Pro data was statistically less accurate than the Pictometry and Google Earth Pro data, while both of which were found to be not different statistically in terms of accuracy. The areal feature area measurements were not normally distributed and therefore tested for equal medians using a Kruskal-Wallis test. The test found that there was no significant difference between sample medians, indicating that all three methods of estimating area are statistically equal in accuracy. The results indicate that Pictometry and Google Earth Pro could both be used to accurately estimate linear feature lengths remotely in lieu of in situ linear measurements while all three remote sensing techniques can be used to accurately estimate areal feature areas remotely in lieu of in situ areal measurements.
\end{abstract}

Keywords: unmanned aircraft system, spatial science, hands-on, forestry, natural resources

\section{Introduction}

Unmanned Aircraft Systems (UAS) or drones are being integrated into undergraduate forestry education for students completing a Bachelor of Science degree in Forestry in the Arthur Temple College of Forestry and Agriculture and (ATCOFA) at Stephen F. Austin State University (SFASU), Nacogdoches, Texas, USA. The addition of UAS complements the mission of ATCOFA by integration of UAS into coursework for both graduate and undergraduate education. Individual UAS research projects enhance one-on-one education due to the need for a pilot-in-command and a visual observer for each project adding to the faculty-student interaction. Once projects are completed, they are developed into outreach program for natural resource education based on real world applications. (Bullard et al., 2014). In Spatial Science, Forestry and Environmental Science, UAS are enhancing interactive hands-on experiences for students (Unger, Hung, Zhang, \& Kulhavy, 2018).

Courses, students, and faculty within ATCOFA focus on hands-on instruction, field exercises, and real-world applications using the most current geospatial technology, most recently through the introduction of small Unmanned Aircraft Systems (UAS), or drones into forestry education to quantify natural resources (Unger, Kulhavy, Hung, \& Zhang, 2014). To begin the use of UAS, students review the Mentored Undergraduate Scholarship (MUGS) rubric on use of UAS to gain confidence in understanding of UAS for teaching and research and service (Unger, Kulhavy, Busch-Petersen, \& Hung, 2016). This promotes critical thinking, technical knowledge and skill, hands-on engagement, and construction of new concepts for use of UAS in education (Sattar, Tamatea, \& Nawaz, 2017).

To learn to use the UAS in forestry education, students begin with safety and set up of the UAS followed by an exercise in hazard rating of urban tress (Kulhavy, Wu, Unger, Hung, \& Sun, 2016; Kulhavy, Unger, Hung, \& Zhang, 
2016) to gain control of the UAS and review the connection of the controller to the aircraft (Watts, Ambrosia, \& Hinckley, 2012). Students are introduced to the use of Pix4DCapture application to collect data for an orthomosaic of an area (Kulhavy \& Unger, 2016; Kulhavy et al., 2016). Forestry students interested in obtaining additional experience and hands-on use of UAS enroll in a voluntary training course combining a study guide and use of a UAS in assessing natural resources. The course combines use of the FAA remote pilot test preparation book with guided instruction and safety in the use of UAS.

All operations of UAS occur under the FAA Modernization and Reform Act of 2012, Subtitle B, Unmanned Aircraft Systems, Sec. 331. UAS, better known as drones, are powered aircraft and associated elements, including communication links and controls, operated remotely or autonomously under the operation of a remote pilot-in-command (Hugenholtz, Moorman, Riddell, \& Whitehead, 2012; Public Law 112-95, 2012). Students wishing to pursue the use of UAS further into natural resources or fly for commercial purposes complete a training course in FAA Part 107 and show competency in the controls of a UAS prior to applying for their FAA Remote Pilot Certificate.

As a result of training, a forestry undergraduate student completed measurements of 30 linear and areal features with a DJI Phantom 4 Pro UAS and compared these measurements to onscreen Pictometry hyperspectral imagery; and Google Earth Pro interface to evaluate and compare the effectiveness of each method.

\section{Literature Review}

\subsection{The Need for Accurate, Current Surface Measurements}

The spatial location and boundary of geographic features is crucial to measuring a natural resource. Knowing the length and area of features on the Earth's surface is essential for a forestry endeavor for management of the landscape and its surface features. To create a management plan for a forest stand, size and perimeter of the stand are essential (Unger, 2014; Unger et al., 2013). Although the linear measurements and areal measurements can be estimated in situ with a basic GPS unit or other measuring device, these methods can be time consuming and expensive for a large geographic area (Unger et al., 2013; Unger, Kulhavy, Hung, \& Zhang, 2014).

Remote sensing obtains information about the Earth's surface from a distance using electromagnetic energy, typically in the form of aerial photographs or digital imagery to quantify and qualify natural resources (Campbell \& Wynne, 2011). Remote sensing is advantageous due to the acquisition of information of a given area quickly and efficiently, thereby reducing time and cost for data acquisition.

\subsection{Pictometry Data}

Hyperspatial resolution multispectral Pictometry (Pictometry International Corporation, now merged with EagleView Technologies, Bothell, WA) data are available in a web-based interface for linear and areal measurements on the Earth's surface. Pictometry is acquired using low-flying aircraft to obtain images to create a georeferenced orthomosaic image allowing for the estimation of surface object size within seconds through the Pictometry web-based interface (Dailey, 2008; Gerke \& Kerle, 2011; Wang, Schultz, \& Giuffrida, 2008). Pictometry can be used for height, linear and areal measurements on the Earth's surface (Unger, Kulhavy, Williams, Creech, \& Hung, 2015; Unger, Hung, \& Kulhavy, 2014; Kulhavy, Unger, Hung, \& Douglass, 2014; Kulhavy, Unger, Zhang, Bedford, \& Hung 2016; Unger, Kulhavy, Hung, \& Zhang, 2016).

\subsection{Google Earth Pro Data}

Google Earth Pro (Google, LLC, Mountain View, CA) is a free, internet-based platform providing the users with hyperspatial resolution remotely sensed data. It is accessible by internet connection and has no licensing requirements that other commercial applications may impose. Google Earth Pro provides a simple user-friendly easy-to-learn interface creating a faster learning environment and application of use for undergraduate students (Lisle, 2006; Hu et al., 2013; Patterson, 2007). Google Earth Pro imagery is acquired using multispectral cameras in satellites to capture images which are used to create georeferenced orthomosaic images available for users in the Google Earth Pro interface (Goodchild, 2008; Henley, Unger, Kulhavy, \& Hung, 2016).

\subsection{Surface Measurements Using a UAS}

As UAS continue to improve and become more prevalent in natural resources, measurements must be taken accurately from UAS data. Traditionally, surface measurements of Earth's features are taken in situ using various forms of GPS units or tape measures. These methods of measurement quickly become time consuming and expensive. To eliminate the need for in situ measurements, aerial photographs taken from planes or satellites may be used to remotely measure the features on the Earth's surface (Zhang \& Kovacs, 2012; Whitehead \& Hugenholtz, 
2014). These data (images) may not be recently taken, up-to-date photographs so the features to be measured may not be shown (Unger, Kulhavy, \& Hung, 2013). The use of UAS for surface measurements allows the most recent, current aerial photographic data to be taken and analyzed quickly and efficiently.

\section{Methods}

\subsection{Study Site}

The SFASU Commuter Parking Lot (Figure 1) was chosen as the study site due to the proximity and accessibility to SFASU students and faculty and its clearly defined lines that have not changed between the times the aerial imagery, imagery with the drone, and measurements with a tape measure were taken.

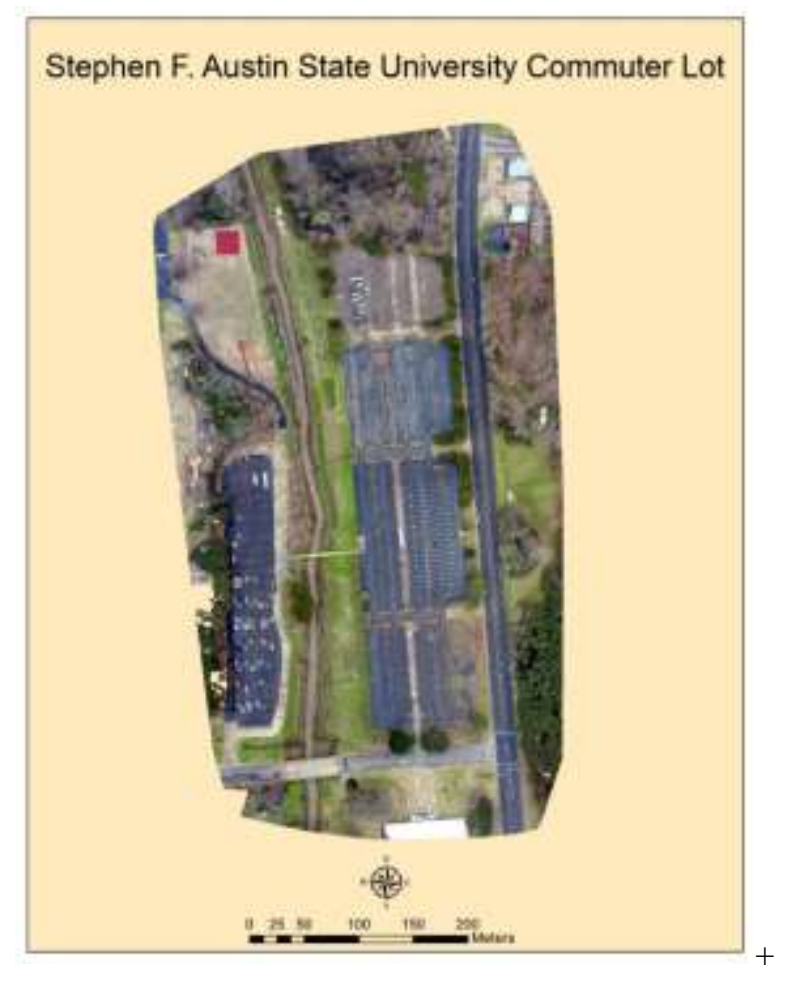

Figure 1. Study site depicting the Commuter Parking Lot on the SFASU Campus.

\subsection{Hands-On Computer Measurements in the GIS Lab}

Undergraduate coursework for the use of UAS in hands-on computer measurements in the Forestry and Spatial Science programs within ATCOFA combines traditional classroom instruction with one-on-one faculty interaction in the use of the UAS to collect remotely sensed data. The students then download the information from the UAS into ArcGIS 10.5.2 in the GIS laboratory, or use Drone2Map software to create an orthomosaic for use in the computerized environment (Figure 1). The collection of the UAS data coupled with the hands-on instruction in the GIS laboratory produces a more well-rounded and more competent graduate in cutting edge spatial science software necessary for the workforce (Bullard et al., 2014).

In 2013 and 2016 ATCOFA acquired Pictometry imagery in partnership with the County of Nacogdoches 911 District, the City of Nacogdoches, Texas, and the Nacogdoches County Appraisal District. The purchase included Pictometry imagery covering the City of Nacogdoches at $10.2 \mathrm{~cm}$ spatial resolution in 2013 and the entire County of Nacogdoches at $23.0 \mathrm{~cm}$ spatial resolution in 2013 and 2016; the typical spatial resolution acquired with Pictometry data representing local neighborhoods and community level coverage respectfully (EFS, 2007). A forestry undergraduate student was instructed how to measure the length and area of surface features remotely using the Pictometry web-based interface. Pictometry data with image acquisition date of the SFASU Commuter Parking Lot of February 2016 were chosen since the spatial resolution was the highest while still having the current lines in the parking lot. The student was shown how to measure linear distances and areas within the Pictometry web-based interface, then recorded the measurements himself (Figures $2 \& 3$ ). 


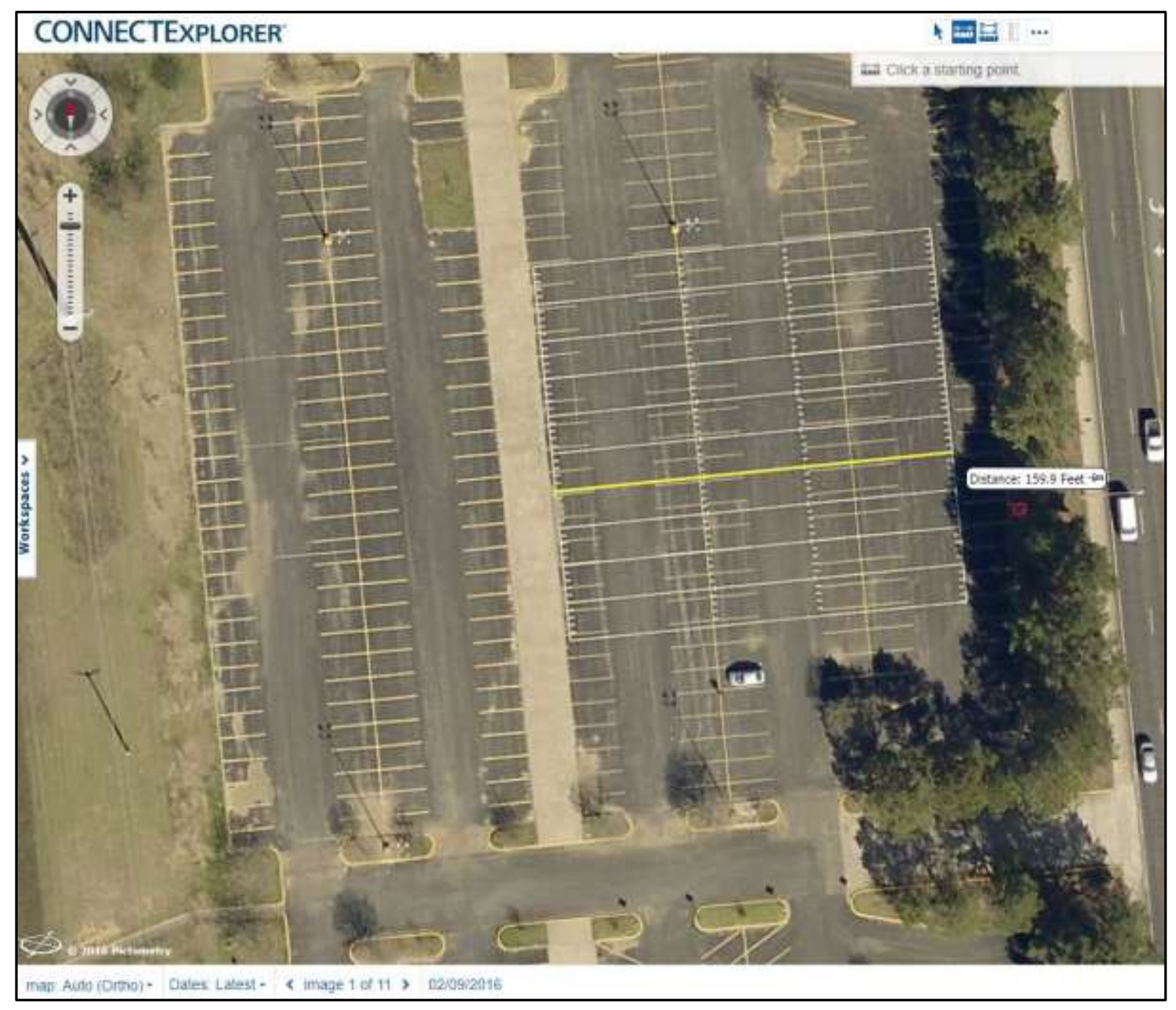

Figure 2. Example of estimating linear feature length within the Pictometry web-based interface. 


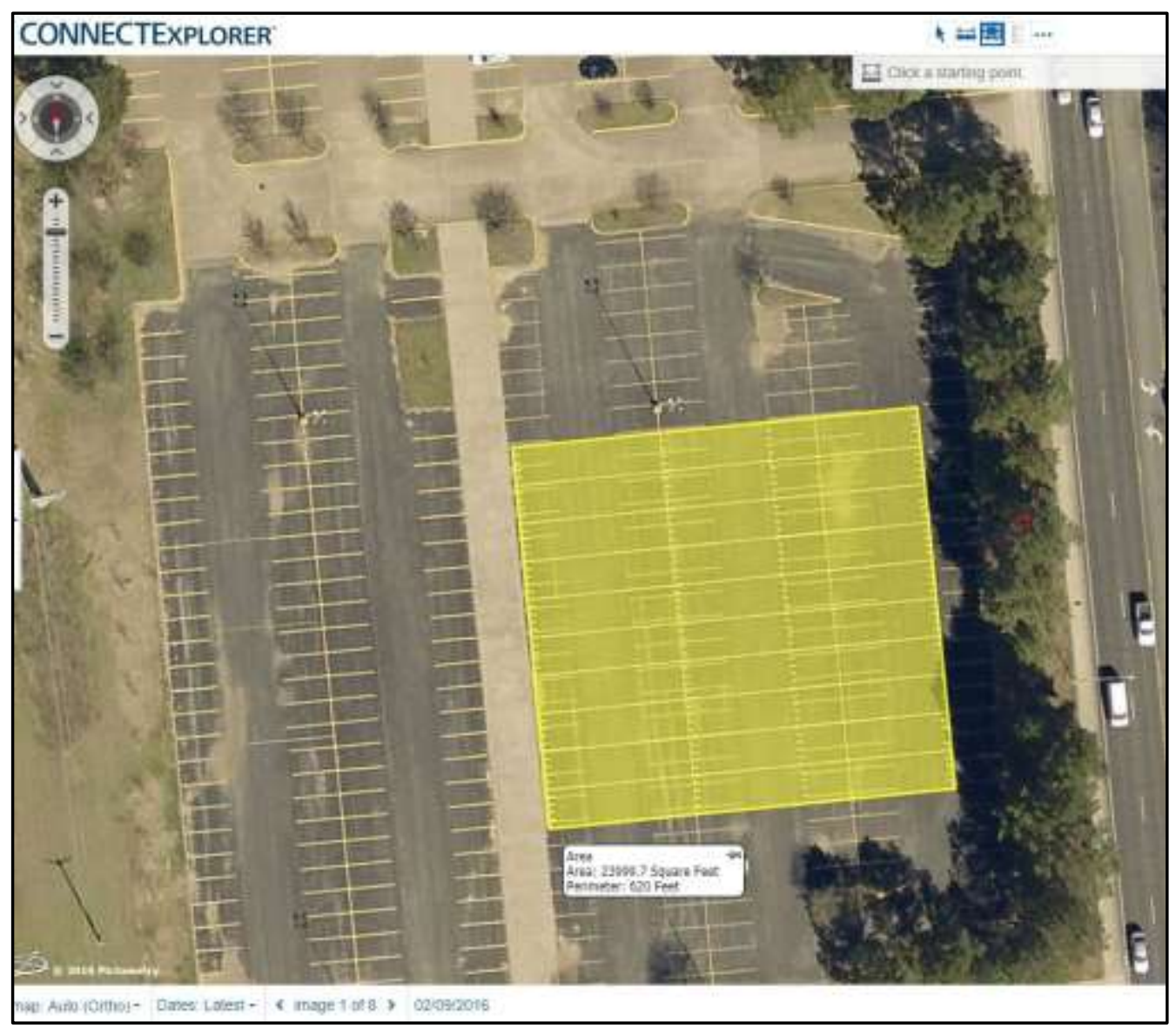

Figure 3. Example of estimating feature area within the Pictometry web-based interface.

Google Earth Pro software is available to all students through the ATCOFA GIS Laboratories. The forestry student was instructed how to measure the linear distances and areas of surface features remotely using Google Earth Pro 7.1.8.3036 (32-bit) developed by Google Inc. (Mountain View, California). Imagery data taken November 2015 was chosen as this was the most recent imagery data displayed for Nacogdoches, Texas. Once the student learned how to measure linear distances and areas within the Google Earth Pro interface, the student was allowed to record measurements himself (Figures $4 \& 5$ ).

\subsection{UAS Measurements}

The student was also introduced to remotely collecting field data measurements using a DJI Phantom 4 Pro drone, or UAS. Under the FAA Regulations Part 336, a model aircraft or UAS weighing less than 55 pounds may be flown for hobby or recreational use following other regulations listed in Part 107 (Federal Register, 2016). After being introduced to the DJI Phantom 4 Pro, the student took part in a class to receive the FAA Part 107 UAS Remote Pilot Certificate. After completing the class, the student flew the DJI Phantom 4 Pro using Pix4DCapture app on an iPhone to create an orthomosaic image of the SFASU Commuter Parking Lot (study site, Figure 1). The images captured on the DJI Phantom 4 Pro were then downloaded to a computer in the ATCOFA GIS Laboratories and input into the Drone2Map software. The Drone2Map software created a georeferenced orthomosaic image of the parking lot that was then opened in ArcMap 10.5.2. The measurement tool in ArcMap 10.5.2 was introduced to the student and used to record the estimated length of the linear features and area of the polygon features to attain the drone measurements. 


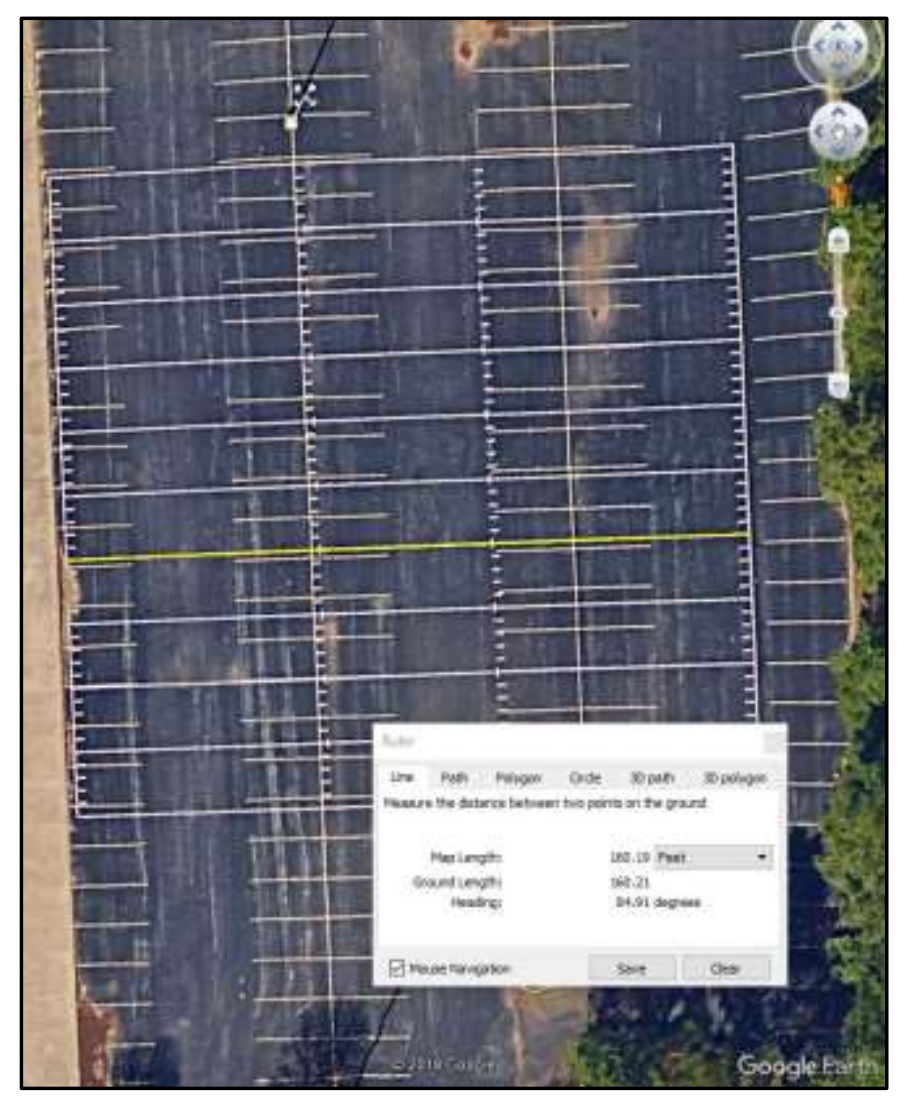

Figure 4. Example of estimating linear feature length within the Google Earth Pro interface.

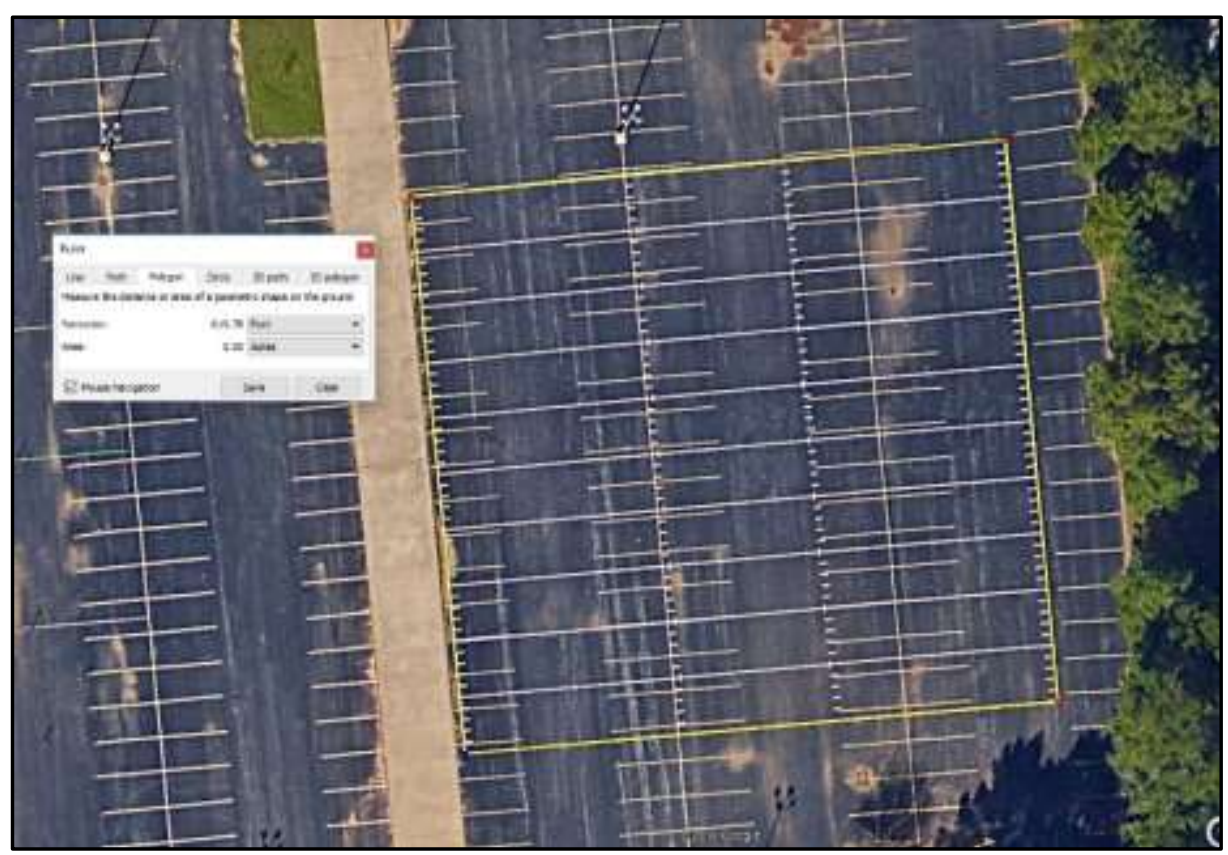

Figure 5. Example of estimating feature area within the Google Earth Pro interface. 


\subsection{Field Measurements}

Once the Pictometry, Google Earth Pro, and the drone measurements were recorded, the student went to the field and used a 300-foot tape to measure the 30 lines and 30 rectangles on the ground to the nearest tenth of a foot. These measurements were later used as the true measurements for the statistical analysis.

\subsection{Statistical Analysis}

To assess the accuracy of the remotely sensed measurements from the UAS and Pictometry, and ATCOFA's hands-on instruction methodology, each set of the 60 (30 lines and 30 rectangles) estimates by Pictometry, Google Earth Pro, and UAS respectively, were compared to the actual measurements that were recorded in situ with a tape measure. For each remote sensing method assessed, measurement errors were calculated for mean error, mean absolute error, mean absolute percent error, and root mean square error. An analysis of variance (ANOVA) was conducted on the absolute length and area errors to determine if accuracy differences in measurement among the three remote sensing methods tested were statistically different. When found significant, a Tukey pair-wise test was applied to identify how the three remotely sensed height estimation techniques differed in accuracy.

\section{Results}

A summary of all 30 linear feature in situ measurements and all 30 remotely sensed linear feature estimates using Pictometry data, Google Earth Pro data, and a DJI Phantom 4 Pro are displayed in Table 1 and for areal features in Table 2. On average, the DJI Phantom 4 Pro overestimated linear feature length, while Pictometry and Google Earth Pro underestimated the linear features. All mean errors were within one foot with $0.780 \mathrm{ft}$ for DJI Phantom 4 Pro, $-0.239 \mathrm{ft}$ for Google Earth Pro, and $-0.200 \mathrm{ft}$ for Pictometry estimates. For an average accuracy comparison, the DJI Phantom 4 Pro data were found the least accurate among the three, with the highest mean absolute error of $0.780 \mathrm{ft}$ and the highest RMSE of $0.818 \mathrm{ft}$ (Table 3). A summary of all 30 areal feature in situ measurements and all 30 remotely-sensed areal feature estimates using Pictometry data, Google Earth Pro data, and a DJI Phantom 4 Pro are displayed in Table 2. On average, all 3 areal feature estimate methods overestimated the features' areas. All mean errors were within $30 \mathrm{ft}^{2}$ with $29.331 \mathrm{ft}^{2}$ for the DJI Phantom 4 Pro, $8.878 \mathrm{ft}^{2}$ for Google Earth Pro, and $19.000 \mathrm{ft}^{2}$ for the Pictometry estimates. For an average accuracy comparison, the DJI Phantom 4 Professional data were found the least accurate among the three, with the highest mean absolute error of $29.331 \mathrm{ft}^{2}$ and the highest RMSE of 34.772 $\mathrm{ft}^{2}$ (Table 4).

The forestry undergraduate student performed ANOVA on the absolute errors to determine if the accuracy on linear feature estimates among the three remote sensing methods was statistically significant. It resulted in a p-value of 0.0000577, concluding that the three different linear estimating methods were statistically different at the $95 \%$ confidence interval (Table 5). A Tukey pair-wise test was performed and found that the DJI Phantom 4 Pro method was significantly less accurate than others, while there is no difference between Pictometry and Google Earth Pro (Table 6). In measuring linear feature length, the Pictometry estimated length on screen within the Pictometry web-based interface achieved the same level of accuracy as using Google Earth Pro, while the linear feature length estimated from the drone orthomosaic in ArcMap 10.5.2 was statistically less accurate.

The areal feature measurements were tested for normality using Shapiro-Wilk test. It was found that the data were not normally distributed even after transformation. The data were then tested for equal medians using a Kruskal-Wallis test. The test found that there is no significant difference between sample medians, indicating that all three methods of estimating area are statistically the same in accuracy (Table 7). 
Table 1. Summary of all 30 linear feature actual length measurements and in situ length estimates.

\begin{tabular}{|c|c|c|c|c|}
\hline Number & Actual Length (ft) & Pictometry (ft) & Google Earth Pro (ft) & Drone $(\mathrm{ft})$ \\
\hline 1 & 150.6 & 151.1 & 150.4 & 151.3 \\
\hline 2 & 150.6 & 149.6 & 150.5 & 151.3 \\
\hline 3 & 150.5 & 150.1 & 149.4 & 151.1 \\
\hline 4 & 160.4 & 159.4 & 159.6 & 161.3 \\
\hline 5 & 160.5 & 159.9 & 159.9 & 161.3 \\
\hline 6 & 161.0 & 160.1 & 160.4 & 161.4 \\
\hline 7 & 160.4 & 160.2 & 160.1 & 161.3 \\
\hline 8 & 160.4 & 160.0 & 159.7 & 161.3 \\
\hline 9 & 161.0 & 159.8 & 160.0 & 161.4 \\
\hline 10 & 160.3 & 159.9 & 160.2 & 161.2 \\
\hline 11 & 160.4 & 160.3 & 160.2 & 161.3 \\
\hline 12 & 160.3 & 160.1 & 159.9 & 161.3 \\
\hline 13 & 160.4 & 160.0 & 159.9 & 161.3 \\
\hline 14 & 160.2 & 158.6 & 160.0 & 161.0 \\
\hline 15 & 300.7 & 300.1 & 299.3 & 302.0 \\
\hline 16 & 300.8 & 300.4 & 300.2 & 302.0 \\
\hline 17 & 300.8 & 300.0 & 300.0 & 302.0 \\
\hline 18 & 300.6 & 300.0 & 299.7 & 301.8 \\
\hline 19 & 160.5 & 161.1 & 160.6 & 161.3 \\
\hline 20 & 160.5 & 161.2 & 160.6 & 161.1 \\
\hline 21 & 160.5 & 160.7 & 160.8 & 161.1 \\
\hline 22 & 160.5 & 160.7 & 160.7 & 161.0 \\
\hline 23 & 160.5 & 160.8 & 160.7 & 161.0 \\
\hline 24 & 160.5 & 160.6 & 160.9 & 161.1 \\
\hline 25 & 160.5 & 161.0 & 160.7 & 161.0 \\
\hline 26 & 160.5 & 160.5 & 160.6 & 161.0 \\
\hline 27 & 160.5 & 160.5 & 160.9 & 161.2 \\
\hline 28 & 160.5 & 160.7 & 160.8 & 161.0 \\
\hline 29 & 160.5 & 160.9 & 160.8 & 161.0 \\
\hline 30 & 160.4 & 160.7 & 160.7 & 161.0 \\
\hline Mean & 178.2 & 178.0 & 177.9 & 179.0 \\
\hline
\end{tabular}


Table 2. Summary of all 30 areal feature measurements and in situ area estimates.

\begin{tabular}{|c|c|c|c|c|}
\hline Number & Actual Area $\left(\mathrm{ft}^{2}\right)$ & Pictometry $\left(\mathrm{ft}^{2}\right)$ & Google Earth Pro $\left(\mathrm{ft}^{2}\right)$ & Drone $\left(\mathrm{ft}^{2}\right)$ \\
\hline 1 & 2424.5 & 2430.2 & 2428.5 & 2451.5 \\
\hline 2 & 2406.1 & 2414.9 & 2417.2 & 2450.6 \\
\hline 3 & 2407.5 & 2428.3 & 2371.8 & 2428.0 \\
\hline 4 & 2415.3 & 2416.5 & 2391.9 & 2451.2 \\
\hline 5 & 2406.6 & 2448.1 & 2417.5 & 2426.0 \\
\hline 6 & 2406.7 & 2417.0 & 2418.5 & 2425.2 \\
\hline 7 & 2415.3 & 2404.5 & 2378.9 & 2441.1 \\
\hline 8 & 2404.5 & 2409.2 & 2435.4 & 2425.4 \\
\hline 9 & 2406.2 & 2401.6 & 2403.6 & 2425.1 \\
\hline 10 & 2404.5 & 2438.1 & 2410.9 & 2440.5 \\
\hline 11 & 2406.1 & 2424.7 & 2466.3 & 2421.8 \\
\hline 12 & 2408.6 & 2416.8 & 2413.8 & 2423.4 \\
\hline 13 & 2403.6 & 2408.6 & 2411.3 & 2420.4 \\
\hline 14 & 4815.8 & 4866.3 & 4876.1 & 4889.4 \\
\hline 15 & 4815.6 & 4857.2 & 4875.7 & 4889.7 \\
\hline 16 & 4815.9 & 4842.0 & 4875.2 & 4853.3 \\
\hline 17 & 4815.4 & 4854.2 & 4834.7 & 4849.9 \\
\hline 18 & 4815.4 & 4824.3 & 4788.8 & 4859.3 \\
\hline 19 & 4815.8 & 4835.0 & 4826.2 & 4855.5 \\
\hline 20 & 2407.5 & 2475.0 & 2454.2 & 2482.3 \\
\hline 21 & 2407.5 & 2436.5 & 2347.0 & 2408.5 \\
\hline 22 & 2407.6 & 2436.8 & 2468.3 & 2439.7 \\
\hline 23 & 2407.5 & 2412.2 & 2384.9 & 2413.6 \\
\hline 24 & 2407.4 & 2354.2 & 2407.6 & 2433.9 \\
\hline 25 & 2407.4 & 2408.6 & 2380.3 & 2409.0 \\
\hline 26 & 2407.7 & 2457.8 & 2405.8 & 2420.8 \\
\hline 27 & 2407.5 & 2414.9 & 2413.2 & 2441.2 \\
\hline 28 & 2407.5 & 2417.8 & 2413.8 & 2421.7 \\
\hline 29 & 2406.3 & 2427.8 & 2400.1 & 2433.0 \\
\hline 30 & 2406.0 & 2481.0 & 2438.6 & 2438.1 \\
\hline Mean & 2889.6 & 2908.7 & 2898.5 & 2919.0 \\
\hline
\end{tabular}


Table 3. Mean error, mean absolute error, and RMSE for all 30 remotely sensed linear feature estimates.

\begin{tabular}{lrrrr}
\hline & & \multicolumn{2}{c}{ Measurement Method } & \\
\cline { 3 - 5 } Error Assessment & Actual Length & Pictometry & Google Earth Pro & Drone \\
\hline Mean Length (ft) & 178.200 & 178.000 & 177.900 & 179.000 \\
Mean Error (ft) & $\mathrm{n} / \mathrm{a}$ & -0.200 & -0.239 & 0.780 \\
Mean Absolute Error (ft) & $\mathrm{n} / \mathrm{a}$ & 0.491 & 0.455 & 0.780 \\
RMSE (ft) & $\mathrm{n} / \mathrm{a}$ & 0.603 & 0.562 & 0.818 \\
\hline
\end{tabular}

Table 4. Mean error, mean absolute error, and RMSE for all 30 remotely sensed areal feature estimates.

\begin{tabular}{|c|c|c|c|c|}
\hline \multirow[b]{2}{*}{ Error Assessment } & \multirow[b]{2}{*}{ Actual Area } & \multicolumn{3}{|c|}{ Measurement Method } \\
\hline & & Pictometry & Google Earth Pro & Drone \\
\hline Mean Area $\left(\mathrm{ft}^{2}\right)$ & 2889.600 & 2908.700 & 2898.500 & 2919.000 \\
\hline Mean Error $\left(\mathrm{ft}^{2}\right)$ & $\mathrm{n} / \mathrm{a}$ & 19.000 & 8.878 & 29.331 \\
\hline Mean Absolute Error $\left(\mathrm{ft}^{2}\right)$ & $\mathrm{n} / \mathrm{a}$ & 23.600 & 25.092 & 29.331 \\
\hline $\operatorname{RMSE}\left(\mathrm{ft}^{2}\right)$ & $\mathrm{n} / \mathrm{a}$ & 31.025 & 32.737 & 34.772 \\
\hline
\end{tabular}

Table 5. Summary table of an ANOVA analysis of absolute error for the linear feature estimates.

\begin{tabular}{lllllll}
\hline SUMMARY & & & & & & \\
\cline { 1 - 5 } Group & Count & Sum & Average & Variance & & \\
\cline { 1 - 5 } Pictometry & 30 & 13.6 & 0.45183 & 0.119285 & & \\
Google Earth Pro & 30 & 13.6 & 0.45450 & 0.113533 & & \\
Drone & 30 & 23.4 & 0.78037 & 0.062260 & & \\
\hline ANOVA & & & & & & \\
\cline { 1 - 5 } Source of Variation & SS & df & MS & F & P-value & F \\
\hline Between Groups & 0.189 & 3 & 0.06303 & 8.141 & 0.000058 & 2.68281 \\
Within Groups & 0.898 & 116 & 0.00774 & & & \\
Total & 1.087 & 119 & & & & \\
\hline
\end{tabular}

Table 6. Results from a Tukey pair-wise test.

\begin{tabular}{llll}
\hline Measurement Method & Pictometry & Google Earth Pro & Drone \\
\hline Pictometry & & 0.9701 & 0.0020070 \\
Google Earth Pro & & 0.0004969 \\
\hline
\end{tabular}

Table 7. Results from a Kruskal-Wallis test for equal medians.

\begin{tabular}{llll}
\hline Measurement Method & Pictometry & Google Earth Pro & Drone \\
\hline Pictometry & & 0.7618 & 0.1668 \\
Google Earth Pro & 0.7618 & & 0.2458 \\
Drone & 0.1668 & 0.2458 & \\
\hline
\end{tabular}




\section{Discussion}

The findings demonstrate that the use of a drone in natural resources management allows for the acquisition of the most up-to-date data that can be used to conduct measurement estimates remotely with the same accuracy of other commonly used mapping applications. An undergraduate forestry student under the direction of GIS faculty estimated the length and area of surface features from a distance using remotely sensed data. The high-level accuracy of the student conducted length and areal estimates validates the hands-on instruction within the Bachelor of Science programs in Forestry, Environmental and Spatial Science within ATCOFA at SFASU.

The findings also validate the interactive nature of the instruction methodology employed by faculty with ATCOFA which could be applied within other colleges and departments at SFASU or other academic institutions. By focusing on an interactive hands-on approach within an applied setting, the utility of integrating remotely sensed technology within the spatial science program at SFASU was shown to be an effective tool at obtaining real-world measurements using cutting edge technology. In the future this combination of spatial science high end technology integration should be assessed within other academic disciplines to validate the use of spatial science as a multidisciplinary tool across a host of academic endeavors.

\section{Conclusions}

The ease of remotely sensed length and area estimation demonstrated by a forestry undergraduate student using the web-based Pictometry interface, Google Earth Pro interface, and DJI Phantom 4 Pro data with ArcMap 10.5.2 GIS software reinforces the use of these methods to remotely estimate length and area in lieu of in situ assessments. A Tukey pair-wise test found that the remotely sensed Pictometry web-based interface and Google Earth Pro interface were statistically the same in accuracy for the linear length measurements while the DJI Phantom 4 Pro data in the ArcMap 10.5.2 interface were statistically less accurate. The results indicate that linear estimates within the Pictometry web-based interface and Google Earth Pro could be used in lieu of time consuming or more costly in situ linear measurements. Per the results, any of the three methods used in the study will achieve the same level of accuracy statistically for estimations of area measurements. This allows for the drone, which is user controlled and can by flown at a given time and place at the discretion of the user, to be the most beneficial as the images and data will be the most up-to-date out of the three remote sensing options analyzed.

\section{Acknowledgements}

This research was supported by McIntire Stennis Cooperative Research funds administered by the Arthur Temple College of Forestry and Agriculture.

\section{References}

Bullard, S. H., Stephens Williams, P., Coble, T., Coble, D. W., Darville, R., \& Rogers, L. (2014). Producing "society-ready" foresters: A research-based process to revise the Bachelor of Science in Forestry curriculum at Stephen F. Austin State University. Journal of Forestry, 112(4), 354-360. https://doi.org/10.5849/jof.13-098

Campbell, J. B., \& Wynne, R. H. (2011). Introduction to Remote Sensing. New York, New York: The Guilford Press.

Dailey, S. W. (2008). An accuracy assessment of 3-dimensional measurements derived from LiDAR and Pictometry data when compared to in situ survey measures. Columbia, South Carolina: M. S. Thesis, University of South Carolina.

Electronic Field Study (EFS). (2007). Electronic Field Study User Guide Version 2.7., Rochester, New York: Pictometry International Corporation.

Federal Register. (2016). Operation and certification of small unmanned aircraft systems. Federal Register 81(124), 42064-42214.

Gerke, M., \& Kerle, N. (2011). Automatic structural seismic damage assessment with airborne oblique Pictometry imagery. Photogrammetric Engineering and Remote Sensing, 77, 885-898. https://doi.org/10.14358/PERS.77.9.885

Goodchild, M. F. (2008). The use cases of digital earth. International Journal of Digital Earth, 1(1), 31-42. https://doi.org/10.1080/17538940701782528

Henley, R. B., Unger, D. R., Kulhavy, D. L., \& Hung, I. (2016). Incorporating applied undergraduate research in senior to graduate level remote sensing classes. International Journal of Higher Education, 5(1), 232-248. https://doi.org/10.5430/ijhe.v5n1p232

Hu, Q., Wu, W., Xia, T., Yu, Q., Yang, P., Li, Z., \& Song, Q. (2013). Exploring the use of Google Earth imagery and 
object-based methods in land use/cover mapping. Remote Sensing, 5(11), 6026-6042. https://doi.org/10.3390/rs5116026

Hugenholtz, C. H., Moorman, B. J., Riddell, K., \& Whitehead, K. (2012). Small unmanned aircraft systems for remote sensing and earth science research. Eos, Transactions American Geophysical Union, 93(25), 236-236. https://doi.org/10.1029/2012EO250005

Kulhavy, D., and Unger, D. (2016). Service-learning and participation in a capstone spatial science course. Journal of Service-Learning in Higher Education, 5, 41-53.

Kulhavy, D. L., Unger, D. R. Grisham, R., Coble, D., Endsley, G., and Gannon, M. (2016). Service learning for the Port Jefferson History and Nature Center: Senior capstone forestry course. Journal of Community Engagement and Higher Education, 9, 67-79.

Kulhavy, D. L., Unger, D. R., Zhang, Y., Bedford, P., \& Hung, I. (2016). Comparing remotely sensed Pictometry web based slope distance estimates with in situ total station and tape slope distance estimates. International Journal of Geospatial and Environmental Research, 3, 1, Article 3, 1-13.

Kulhavy, D. L., Wu, D., Unger, D. R., Hung, I., and Sun, J. (2016). Comparison of tree condition and value for city and parks and Stephen F. Austin State University in Nacogdoches, Texas, U.S. Arboriculture and Urban Forestry, 40, 165-172.

Kulhavy, D. L., Unger, D. R., Hung, I., and Douglass, D. (2014). Integrating hands-on undergraduate research in an applied spatial science senior level course. International Journal of Higher Education, 4, 52-60. https://doi.org/10.5430/ijhe.v4n1p52

Kulhavy, D. L., Unger, D. R., Hung, I., and Zhang, Y. (2016). Comparison of AR.Drone quadricopter video and the visual CTLA method for urban tree hazard rating. Journal of Forestry, 114, 517-523. https://doi.org/10.5849/jof.15-005

Lisle, R. J. (2006). Google Earth: a new geological resource. Geology Today, 22, 1, 29-32. https://doi.org/10.1111/j.1365-2451.2006.00546.x

Patterson, T. C. (2007). Google Earth as a (not just) geography education tool. Journal of Geography, 106(4), 145-152. https://doi.org/10.1080/00221340701678032

Public Law 112-95/ (2012). FAA modernization and reform act of 2012. Superintendent of Documents, United States Printing Office, Washington, https://www.gpo.gov/fdsys/pkg/PLAW-112publ95/pdf/PLAW-112publ95.pdf

Sattar, F., Tamatea, L., \& Nawaz, M. (2017). Drawing the pedagogy: Future prospect of teaching and learning. International Journal of Educational and Pedagogical Sciences, 11(6), 1659-1664.

Unger, D. (2014). Validating one-on-one GPS instruction methodology for natural resource area assessments using forestry undergraduate students. Higher Education Studies, 4(1), 94-102. https://doi.org/10.5539/hes.v4n1p94

Unger, D. R., Hung, I., Zhang, Y., Parker, J., Kulhavy, D. L., \& Coble, D. W. (2013). Accuracy assessment of perimeter and area calculations using consumer-grade global positioning system (GPS) units in southern forests. Southern Journal of Applied Forestry, 37(4), 208-215. https://doi.org/10.5849/sjaf.13-006

Unger, D. R., Kulhavy, D. L., \& Hung, I. (2013). Validating the geometric accuracy of high spatial resolution multispectral satellite data. GIScience \& remote sensing, 50(3), 271-280.

Unger, D., Kulhavy, D., Hung, I., \& Zhang, Y. (2014). Quantifying natural resources using field-based instruction and hands-on applications. Journal of Studies in Education, 4, 1-14. https://doi.org/10.5296/jse.v4i2.5309

Unger, D. R., Hung, I., and Kulhavy, D. L. (2014) Comparing remotely sensed Pictometry ${ }^{\circledR}$ web-based height estimates with in situ clinometer and laser range finder height estimates. Journal of Applied Remote Sensing, 8(1), 083590 (Jul 17, 2014. Doi:10.1117/1.JRS.8.083590).

Unger, D., Kulhavy, D., Williams, J., Creech, D., and Hung, I. (2015). Urban tree height assessment using Pictometry hyperspatial 4-inch multispectral imagery. Journal of Forestry, 113, 7-11. https://doi.org/10.5849/jof.14-020

Unger, D. R., Kulhavy, D. L., Busch-Petersen, K., \& I. Hung, I. (2016). Integrating faculty led service learning training to quantify height of natural resources from a spatial science perspective. International Journal of Higher Education, 5, 104-116. https://doi.org/10.5430/ijhe.v5n3p104

Unger, D., Kulhavy, D., Hung, I., \& Zhang, Y. (2016). Accuracy assessment of Pictometry height measurements 
stratified by cardinal direction and image magnification. International Journal of Geospatial and Environmental Research, 3(1), Article 4. 17 p.

Unger, D., Hung, I., Zhang, Y., \& Kulhavy, D. (2018). Integrating drone technology with GPS data collection to enhance forestry students interactive hands-on field experience. Higher Education Studies, 8, 49-62. https://doi.org/10.5539/hes.v8n3.49

Wang, Y., Schultz, S., \& Giuffrida, F. (2008). Pictometry's proprietary airborne digital imaging system and its application in 3d city modelling. International Archives of Photogrammetry and Remote Sensing, 37, 1065-1069.

Watts, A. C., Ambrosia, V. G., \& Hinkley, E. A. (2012). Unmanned aircraft systems in remote sensing and scientific research: Classification and considerations of use. Remote Sensing, 4, 1671-1992. https://doi.org/10.3390/rs4061671

Whitehead, K., \& Hugenholtz, C. H. (2014) Remote sensing of the environment with small unmanned aircraft systems (UASs). Part 1: A review of progress and challenges. Journal of Unmanned Vehicle Systems, 2(3), 69-85. https://doi.org/10.1139/juvs-2014-0006

Zhang, C., \& Kovacs, J. M. (2012). The application of small unmanned aerial systems for precision agriculture: a review. Precision Agriculture, 13(6), 693-712. https://doi.org/10.1007/s11119-012-9274-5 